\title{
Youth Unemployment and Underdevelopment in Honduras
}

\author{
Luis René Cáceres ${ }^{1}$ \\ ${ }^{1}$ Independent researcher, El Salvador \\ Correspondence: Luis Rene Caceres, 5456 Paseo General Escalon, San Salvador, El Salvador. E-mail: \\ luisrenecaceres@gmail.com
}

Received: November 23, 2020

Accepted: January 23, 2021

Online Published: January 30, 2021

doi:10.5539/ijef.v13n2p61

URL: https://doi.org/10.5539/ijef.v13n2p61

\begin{abstract}
This paper analyzes the determinants and consequences of youth unemployment in Honduras. The study is based on the estimation of error correction models that express youth unemployment in terms of real sector variables. The results indicate that exports, remittances and self employment reduce youth unemployment, while the expansion of the service sector increases it; other results show that youth unemployment is susceptible to economic activity in the other Central American countries, specifically to economic growth in Guatemala, El Salvador and Nicaragua. Youth unemployment exerts negative impacts on Honduras' productivity and on economic growth. The study also highlights the role of education on preventing youth unemployment and the importance of designing a Youth Agenda that would comprise several initiatives that are of special value to Honduran youth. It is hoped that these results would motivate policy makers and society in general to increase investments in the human capital areas so that youth avoid falling into the traps resulting from unemployment.
\end{abstract}

Keywords: employment, economic integration, violence

\section{Introduction}

At present, there is much interest in analyzing the determinants of youth unemployment in developed and developing countries. The interest lies in the high magnitudes of youth unemployment in many countries, higher than the unemployment rates of the adult population. Youth unemployment represents a loss of human capital and therefore undermines economic growth (Mroz \& Savage, 2006). Other authors have pointed out that youth unemployment is a trigger for crime (Chioda, 2017), and for irregular emigration, and that it leads to losses in productivity and innovation (Berlingieri et al., 2004), and undermines social cohesion (Giuliano \& Spilimbergo, 2009).

This paper presents an analysis of the determinants of female and male youth unemployment in Honduras, that is, the unemployment experienced by the population between 15 and 24 years of age. A review of the literature on youth unemployment is presented in the next section. This is followed by the analysis of the data and its statistical properties and a discussion of Honduras' recent economic and labor market developments. The next section presents the estimation of equations that allow identifying the origin of youth unemployment in Honduras. In the estimated equations, in addition to national variables, variables from other Central American countries are included, due to the spillovers of economic growth that occur among the countries of the region. The following sections address the impact of youth unemployment on productivity, employment, and economic growth, and the link between youth unemployment and the percentage of the young population that is not working, in school or in training, Neets. The work ends with a series of conclusions.

It should be mentioned that studies on gender specific youth unemployment are scarce; except for works by Hutengs and Stadtmann (2014) and Banerji, Lin, and Saksonovs (2015) no other studies have appeared in the literature with gender specif analysis, but these two studies are based on the estimation of Okun's Law equations, an approach that has several limitations, as will be seen in this paper.

\section{Review of Literature}

Banerji, Lin, and Saksonovs (2015) have shown that the young population works mainly in sectors that are very susceptible to the economic cycle, such as manufacturing, construction and commerce, which makes youth employment vulnerable to the vicissitudes of the national economy. Likewise, due to their limited experience, firing young people does not have a high opportunity cost for companies (Dunsch, 2016). Scarpetta, Sonnet, and Manfredi (2010) have argued that youth work in temporary contracts that are not renewed in times of economic 
downturns. Particularly vulnerable are youth with low education levels; Bell and Blanchflower (2011) reported that in the US and several European countries the less educated youth were the segment hardest hit by unemployment during the 2008-2009 crisis.

With respect to determinants of youth unemployment, reference is made to Choudhry, Signorelli, and Marelli (2012) who estimated equations with 1980-2005 panel data of 75 countries, reporting that youth unemployment increases with the event of financial crisis and declines with economic growth and the inflation rate.

With respect to Latin American countries, Torres and McKenzie (2020) analyzed youth unemployment in six countries using synthetic panels from household surveys, with age, gender, and level of education as cohorts, obtaing results that showed that as age increases the unemployment rate tends to fall, with the largest drop occurring after 30 years of age. Individuals with college education showed lower unemployment rates, while women had higher incidence of unemployment.

A distinctive characteristic of youth unemployment is its persistence, as has been shown by Ryan (2001), and Choudhry, Marelli, and Signorelli (2010) in an analysis of a panel of 70 countries, and by Caporale and Gil-Alana (2014) for European countries.

Several studies have shown that young people that graduate from college in times of economic recessions not only have difficulties in obtaining employment but their professional life is market by problems not encountered by those who graduated in economic boom times. Khan (2008) has shown that in the US young people who obtained their degree in the years of economic recessions, 1979 and 1980, had for the next 20 years lower salaries, received fewer promotions and reached fewer years of graduate school, than those who obtained their degrees in times of economic dynamism.

Particular interest resides in an extensive literature that has highlighted the serious problems that unemployment causes for the unemployed. The psychological effects have been described by Maustrari, Daly, and Delany (2018) for the case of 14 countries of the European Union, while Clark and Oswald (1994) have shown the impacts of unemployment in terms of increases in divorces, on the incidence of mental depression and the unhappiness of individuals, while Goldsmith, Veums, and Darity Jr. (1996) indicated that people who have experienced unemployment tend to suffer from depression, anxiety, and suicidal tendencies. These phenomena have been found in various countries and has been called the "scars of unemployment".

Young people who go through unemployment also suffer from these problems; studies have shown that young people who experience periods of unemployment have problems finding employment for the rest of their lives, and that when they are again employed they receive relative low wages. Gregg (2001) analyzed the repercussions of youth unemployment in Great Britain and reported that the experience of unemployment between the ages of 27 and 33 gives rise to increases of unemployment by 2 months for every 3 months of unemployment experienced prior to the age of 23. Bell and Blachflower (2011) reported for the case of Great Britain that scar effects are persistent in terms of lower wages and feelings of unhappiness at age 50, but unemployment at age 40 caused no scars at 50. Gregg and Tominey (2005) reported that the experience of youth unemployment manifested itself in lower salaries of 31-41 per cent at age 41. Similar results have been reported by Mroz and Savage (2006).

There is also evidence that the daughters and sons of people who went through periods of unemployment themselves have experiences of unemployment upon reaching adulthood, that is, parents give their experiences of unemployment as "inheritance" to their children (Johnson \& Reid, 1996).

It should be noted that among the possible options for unemployed youth are emigration, withdrawing from school, giving up temporally their job search, or entering the category of the youth that is not working, studying or in training, called Neets. To determine the fate of youth when facing unemployment, it would be necessary to have longitudinal data, which do not exist in Honduras; thus, what is analyzed in this paper are some of the manifestations of the options that youth have taken when faced with unemployment, and the resulting economic implications.

\section{Methods}

\subsection{The Data and Its Characteristics}

The source of the data for the different variables is the World Bank's World Development Indicators. The variables were subjected to unit root tests employing the ADF test, to determine if they were stationary or had unit-roots, with the results that indicated that the following variables were stationary: Credit to the private sector, economic growth rates of Guatemala, Honduras Nicaragua, and Costa Rica, Honduras' per capita GDP, remittances received by Guatemala, El Salvador and Honduras, male youth unemployment and the ratio of 
female youth employment to population. The following variables turned out to be integrated of order 1: services, exports, female youth unemployment, ratio of male youth employment to population, female and male self-employment.

Given that some of the variables under analysis were integrated of order 1 while others were stationary, it was decided to carry out all the estimations utilizing Phillips and Hansen's (1990) Fully Modified Least Squares methodology.

The average and standard deviation of the variables included in this paper are shown on Table1.

Table 1. Averages and standar deviations of variables

\begin{tabular}{lcc}
\hline Variable & Average & Standar deviation \\
\hline Exports* & 48.1962 & 7.7853 \\
Credit* & 39.9522 & 14.8130 \\
Remittances* & 11.4865 & 7.2773 \\
Services* & 53.8984 & 5.6490 \\
Manufacture* & & \\
ESGrowth & 2.8984 & 1.7344 \\
GUAGrowth & 3.6308 & 1.0738 \\
NIGrowth & 3.2381 & 2.7913 \\
Female self employment & 50.6778 & 1.7715 \\
Male self employment & 51.1296 & 2.4001 \\
Growth Productivity & 0.0060 & 0.0288 \\
Growth female employment/Population & 0.0050 & 0.0363 \\
Growth male employment/ & & 1.1829 \\
population & -0.1438 & 0.0264 \\
Growth per capita GDP & 0.0125 & 0.0500 \\
Growth female youth employment/population & -0.0008 & 0.0200 \\
Growth male youth employment/population & -0.0034 & \\
\hline
\end{tabular}

* Percentage of GDP.

\section{Analysis}

\subsection{Context}

In the 1960's and 1970's, when the import substitution model was in effect, Honduras' average annual rates of the per capita economic growth were high, 4.35 and 5.50 percent respectively, but since the 1990's economic dynamism has decreased, as shown on Figure 1. It is in this context of low economic growth rates that Honduras' labor market has evolved in the last three decades.

Starting in the 1990s, there have been falls in the participation of the agricultural and manufacturing sectors in GDP, and increases in the participation of the services sector until 2012, as can be seen in Figure 2. These trends can be associated with a tendency towards economic stagnation.

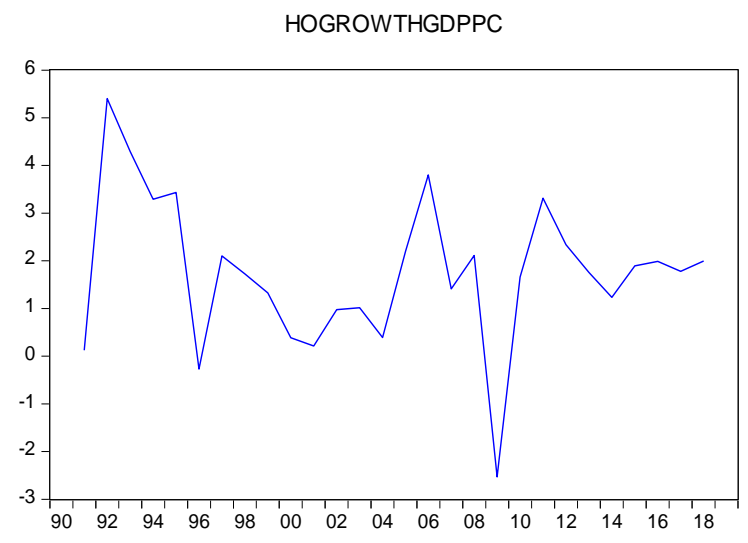

Figure 1. GDP per capita growth rate

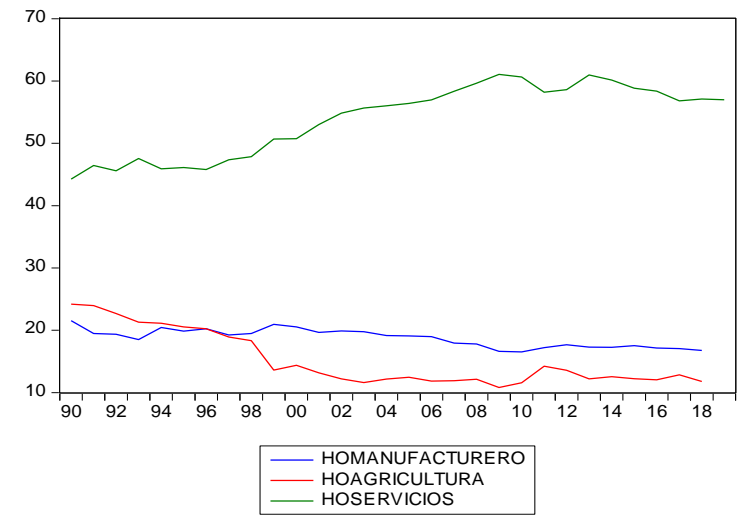

Figure 2. Participations of the service, manufacturing, and agricultural sectors in GDP 
Figure 3 shows a close association between remittances as percentage of GDP (horemesas), and the participation of the services sector in GDP, (hoservicios). Remittances as percentage of GDP fell in 2008 and continued declining until 2013, without having recovered in 2019 their 2006 peak value of 21.7 percent. This downward tendency may have caused the contraction of the services sector.

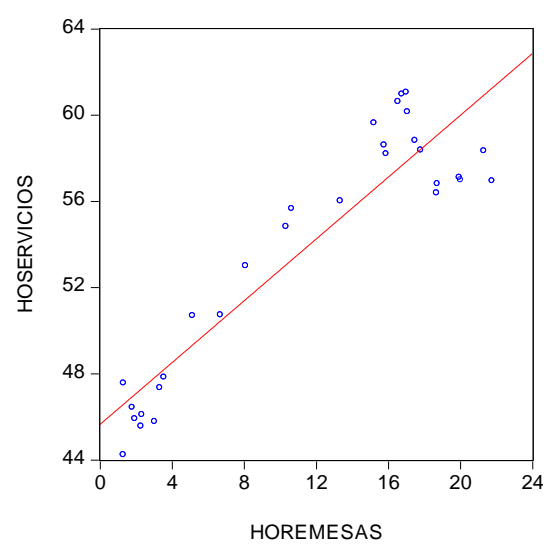

Figure 3. Remittances as a percentage of GDP and participation of the services sector in GDP

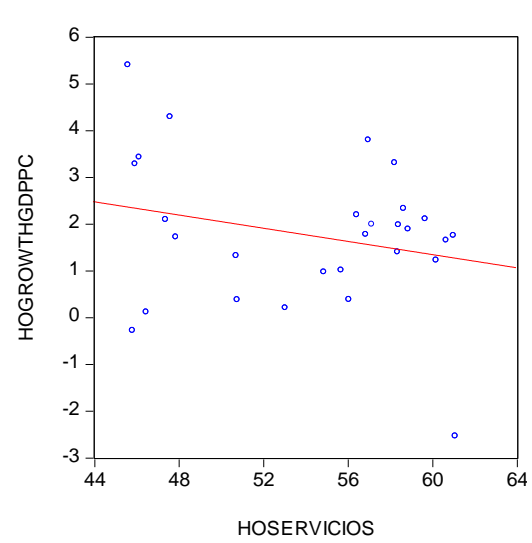

Figure 4. Participation of the services sector in GDP and growth rate of GDP per capita

Figure 4 shows that there is a negative association between the participation of the services sector in GDP, and the rate of per capita economic growth (hogrowthgdppc). This Figure embodies the irony that the largest sector of the economy does not contribute to economic growth.

The tariff on imports was reduced from 50 percent in 1985 to 10 percent in 1995, to drop to 3 percent in 2018 . The extreme openness has led to excessive growth of imports as a percentage of GDP, (hoimports), while exports as a percentage of output (hoexports), have shown a tendency to fall since the mid-1990s, the result of which has been large deficits in the trade account.

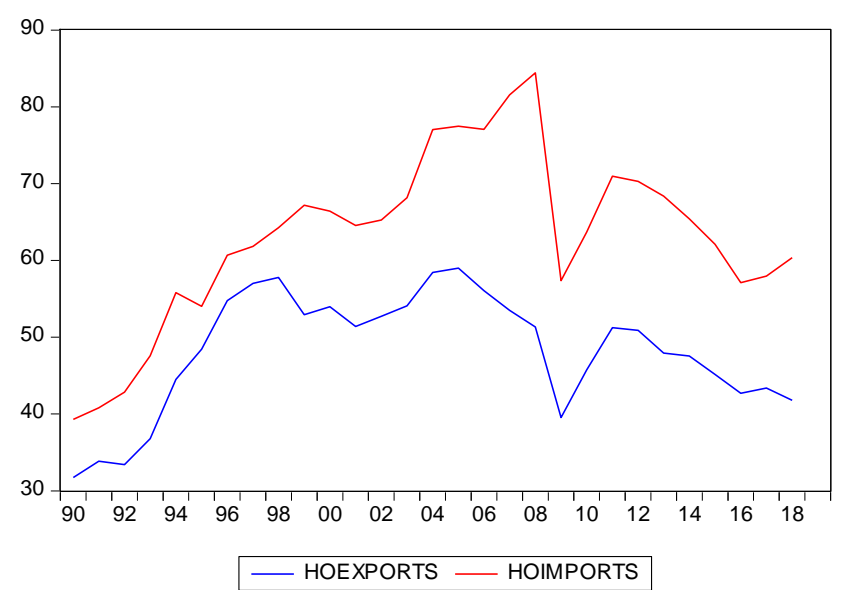

Figure 5. Share of exports and imports in GDP

The deficit in the trade account is explained by the contraction of the participations of the manufacturing and agricultural sectors in GDP, that is, by the deindustrialization and deagriculturization that has occurred in the Honduran economy since the 1990s, as was shown in Figure 2.

Figure 6 shows the female, (hodesempleojovenfeme), and male, (hodesempleojovenmasc), youth unemployment rates in the period 1990-2018. These rates are higher than the unemployment rates of the population between 15 and 61 years old and show high volatility. It is observed that throughout the period the female youth unemployment rate is higher than the male one. The increase in female youth unemployment after 2008 is striking, reaching a maximum value of 22 percent in 2016, to drop to 17 percent in 2019, which can be associated with the fall in the services sector, associated with the decrease in remittances, as was shown on Figure 3. Banerji, Lin, and Saksonovs (2015) reported that male youth employment experiences higher volatility than female youth employment because young men obtain jobs in the manufacturing sector in a higher 
proportion than young women, which is more susceptible to the economic cycle. This is not the case in Honduras, where female youth employment is more susceptible to the economic cycle than male youth employment.

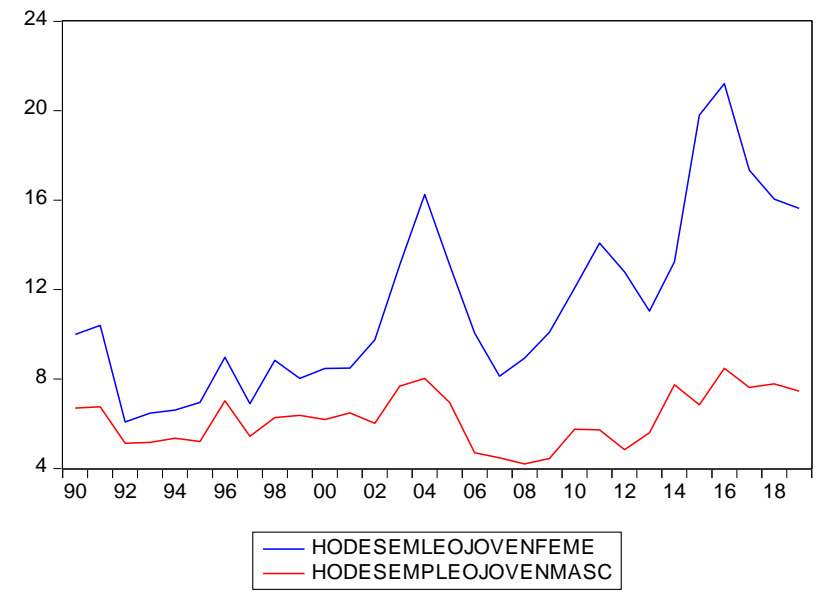

Figure 6. Female and male youth unemployment rates

Recent literature on female employment in the US has indicated that women have a competitive advantage over men in employment in the service sector, as they have "empathy, good character, and kindness", which are characteristics demanded in said sector (Cortes, Jaimovich, \& Siu, 2018). What Figure 6 indicates is that in Honduras the "comparative advantage" of young women lies in the fact that they can be abruptly fired. The job instability of young women is reflected in the fact that Honduras had, in 2010, the highest percentage of female Neets in Latin America, which reached 42.8 percent (de Hoyos, Popova, \& Rogers, 2015), as well as the second-highest adolescent fertility rate, of 85.9 percent.

\subsection{Okun's Law}

As a starting point, an Okun's law type equation was estimated to identify the determinants of youth unemployment. This law expresses the change in the unemployment rate of a given country in terms of its economic growth rate:

$$
D(\text { Unemployment rate })=h-v(\text { Economic growth rate })
$$

Where $\mathrm{D}$ is the first difference operator and $\mathrm{a}$ and $\mathrm{b}$ are the parameters to be estimated.

Okun's seminal work dates from 1962 and since then it has been estimated for different countries; recent studies have shown that Okun's law still is a valid instrument to analyze unemployment in developed and developing countries (Banerji, Lin, \& Saksonovs, 2015; Dunsch, 2016; Cazes, Verick, \&Al Hussani, 2013).

Banerji, Lin, and Saksonovs (2015), estimated Okun law equations desagregating youth by gender, reporting that the Okun coefficients corresponding to young men were larger than those of young women, which was explained by the concentration of young men employed in the industrial sector, which is very susceptible to the bussiness cycle. Other studies have used sectoral output as the independent variable instead of the rate of economic growth, with results that indicated that the service sector has a larger Okun coefficient than that of the manufacturing sector (Apap \& Gravino, 2016). Banerji, Lin, and Saksonovs (2015) reported that when estimating youth unemployment with Okun's law equations the resulting coefficients were smaller when using the growth rate of consumption instead of economic growth.

To check the validity of Okun's law in the case of Honduras, two equations were estimated, with the following results (Note 1):

$\mathrm{D}($ Young female unemployment $)=0.6832-0.1324$ Economic Growth

$\mathrm{R}$ squared $=0.02$

$\mathrm{D}($ Young male unemployment $)=04708-0.1203$ Economic Growth

$\mathrm{R}$ squared $=0.10$

In the equation for the change of female youth unemployment rate, the coefficient of economic growth is negative 
but not significant, while in the equation for the change of male youth unemployment the coefficient is negative and significant, but the $\mathrm{R}^{2}$ is very low.

These results show that it is not possible to analyze the youth unemployment rates in Honduras based on Okun's model and, therefore, it is necessary to look for other variables that could be determining factors. This is the topic discussed below.

4.3 Selection of Variables Associated with Youth Unemployment: Credit, Exports, Services, Foreign Trade, Informality

Credit is especially important given its role in job creation, as demonstrated by Dao and Liu (2017), in their model that highlighted the role of credit in providing the working capital needs of companies. On the other hand, due to its possible inflationary effects, credit could cause a drop in employment, and the results obtained by Dao and Liu would not occur.

It can be expected that exports would reduce unemployment, given that the maquila industry, which is an important source of employment in Honduras, is intensive in female labor.

Remittances can exert a decreasing impact in youth employment since they increase the purchasing power of the population which would lead to a greater demand for goods and services. But they can also be expected to act to increase youth unemployment, given the inflationary pressures they could give rise to.

The service sector is the main source of female and male employement, so it can be assumed that its expansion would lead to falls in youth unemployment. As observed in Figure 2, this sector shows a declining trend since 2013, which may explain the increase in female youth unemployment.

Several studies have shown the influences that the US economy exerts on the Central American economies (Swinton, 2010; Kose \& Rebucci, 2005). Other studies have shown that there is a high reciprocal susceptibility of the Central American economies to developments in the other Central American economies. Exports from Honduras to the other Central American countries reached the sum of 930.5 million dollars in 2017 and, thus, exports destined to Central America can contribute to reducing its unemployment rate. Cáceres (2014) showed with a var model that the increase in economic growth of the aggregation of the economies of El Salvador and Costa Rica led to the fall in the unemployment rate of the economic aggregate of Honduras and Nicaragua, and vice versa.

However, the growth of the United States economy does not have an effect on Honduras' female youth unemployment, (hodesempleojovenfeme), as seen in Figure 7, and has a positive association with male youth unemployment (Figure 8).

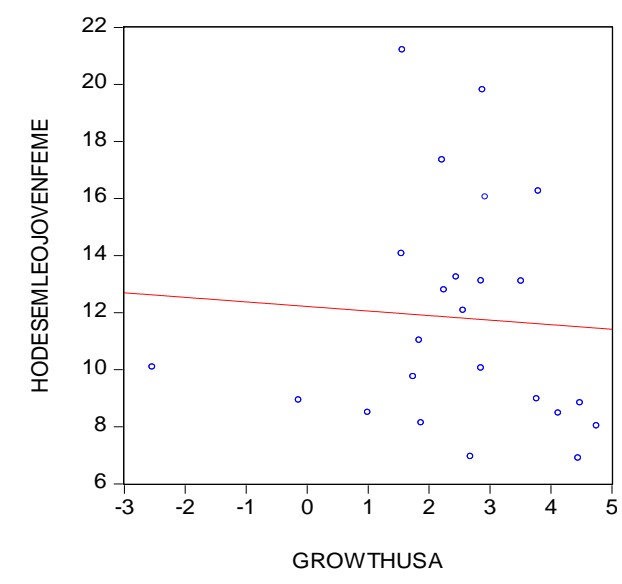

Figure 7. US economic growth rate and female youth unemployment rate

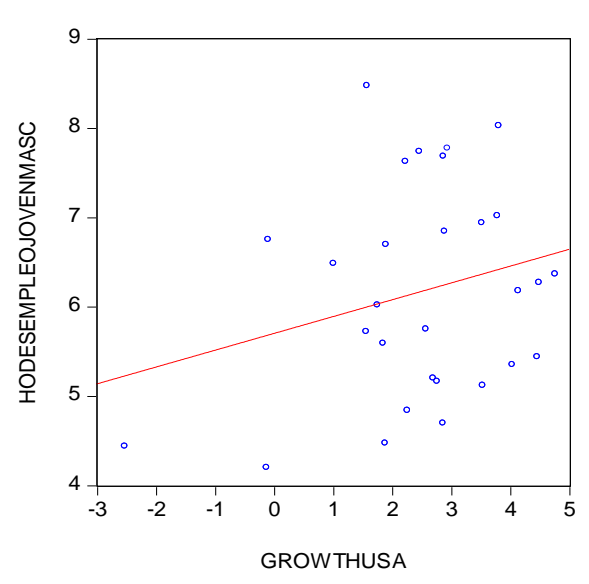

Figure 8. US economic growth rate and male youth unemployment rate

One option for unemployed youth is to work in the informal markets. Cáceres (2013) has presented evidence, based on panel data from 8 Latin American countries, that self-employment, which represents informal employment, increases in response to the increase in the unemployment rate.

It is valid to postulate then that the youth unemployment rate in Honduras responds to variations in credit, exports, services, informality, and the economic growth rates of the other Central American countries. 


\section{Results}

\subsection{Error Correction Model}

The model to be estimated consists of the following rreduced form model, expressed as:

$$
\text { Unemployment }=\text { bo }+W(b i V i)
$$

Where the variable Unemployment represents the female or male youth unemployment rates, bo is a constant, $\mathrm{W}$ is the summation symbol, Vi represent the different variables that are postulated to have impacts on youth unemployment, and bi is their corresponding coefficients.

The above expression can be expressed as the following unconstrained error correction model:

$$
\begin{aligned}
D(\text { unemployment })= & B+\text { Ao unemployment }(-1)+A 1 V 1(-1)+A 2 V 2(-1)+\ldots A n V n(-1) \\
& +c 1 D(V 1)+c 2 D(V 2)+c 3 D(V 3)+\ldots c n D(V n)
\end{aligned}
$$

Where $\operatorname{ciD}(\mathrm{Vi})$ represents the short-term adjustments of the youth unemployment rate in response to the behavior of the variables in first differences; the coefficients of the variables with one year lag represent the long-term impacts of the variables on youth unemployment.

Cointegration tests were carried out as a previous step to the estimation of the error correction model; the application of the Johansen methodology indicated that there were three cointegration vectors in all the error correction models (Note 2). In estimating the equations, Hendry's approach was followed, starting the estimations from the general to the specific until estimating the most parsimonious equation. The dependent variable is the change in the female or male youth unemployment rate, depending on the case. The results of the more parsimonious equation are presented in Table 2 for the change in the female youth unemployment rate.

It is observed that the independent variables exports, female self-employment, and remittances, all with a lag of one year, have negative and significant coefficients, while the share of services in GDP with a lag of one year has a positive sign. The coefficients of the differences in female self-employment and services are negative, and that of credit is positive. The coefficients of El Salvador's and Nicaragua's growth rates lagged one year, as well as the coefficient of the differential in the growth rate of Guatemala, are negative, which means that they contribute to reducing Honduras' female youth unemployment.

It should be noted that the coefficient of the rate of female self-employment lagged one year, as well as its annual change, have negative and large coefficients, indicating the role of informality in accommodating, or giving "shelter", to unemployed young women.

The result that the lagged variables are significant implies that they have long-term relationships with the rate of female youth unemployment.

The qualitative variable Cuali, which represents the economic contraction of 2009, shows a positive and significant coefficient.

Table 2. Determinants of the female youth unemployment rate. Dependent variable: D(Female youth unemployment rate)

\begin{tabular}{lllll}
\hline Variable & Coefficient & Std. Error & t-Statistic & Prob. \\
\hline HOUNEMPLOYMENTYOUNGFEM(-1) & -0.555387 & 0.089516 & -6.204335 & 0 \\
HOEXPORTS(-1) & -0.199479 & 0.070871 & -2.814663 & 0.0156 \\
D(HOCREDIT) & 0.316441 & 0.109867 & 2.880213 & 0.0138 \\
HOREMITTANCES(-1) & -0.30646 & 0.092177 & -3.324683 & 0.0061 \\
CUALI & 3.566271 & 0.752426 & 4.739696 & 0.0005 \\
D(HOSERVICES) & -0.795157 & 0.231309 & -3.437643 & 0.0049 \\
ESGROWTH(-1) & -0.291746 & 0.171945 & -1.696738 & 0.1155 \\
D(GUAGROWTH) & -0.558397 & 0.156034 & -3.578695 & 0.0038 \\
HOSERVICIES(-1) & 0.660965 & 0.114417 & 5.776821 & 0.0001 \\
HOFEMALE SELF EMPLOYMENT(-1) & -0.625741 & 0.221276 & -2.82787 & 0.0152 \\
D(HOFEMALE SELF EMPLOYMENT) & -0.411998 & 0.142143 & -2.898476 & 0.0134 \\
NIGROWTH(-1) & -0.262298 & 0.087186 & -3.008503 & 0.0109 \\
C & 21.38624 & 13.86512 & 1.54245 & 0.1489 \\
R2 & 0.718494 & & & \\
\hline
\end{tabular}


The equation corresponding to the male youth unemployment rate is presented in Table 3. It is observed that the coefficients of remittances and male self-employment, both lagged one year, are negative, while the coefficient of credit lagged one year is positive. The coefficients of the changes in exports and services are positive, while that of the change in male self-employment is negative.

The coefficients of the changes in the economic growth rates of El Salvador and Guatemala are negative, as is the coefficient of the growth rate of Costa Rica lagged one year. This is evidence of the positive role of Central American economic integration in reducing Honduras' youth unemployment. While the issue of youth unemployment has received much attention in the literature, a topic that has not been analyzed is the role that economic integration plays in reducing it.

The variable Cuali has a negative and significant coefficient at the 10 percent level.

Table 3. Determinants of the male youth unemployment rate. Dependent variable: $\mathrm{D}$ (Male youth unemployment rate)

\begin{tabular}{lllll}
\hline Variable & Coefficient & Std. Error & t-Statistic & Prob. \\
\hline HOUNEMPLOYMENT YOUNG MALE(-1) & -0.58161 & 0.119661 & -4.86046 & 0.0004 \\
D(HOEXPORTS) & 0.203979 & 0.031732 & 6.42822 & 0.0000 \\
HOCREDIT(-1) & 0.073204 & 0.015323 & 4.777537 & 0.0005 \\
HOREMITTANCES(-1) & -0.092103 & 0.028563 & -3.224536 & 0.0073 \\
CUALI & -0.555875 & 0.317467 & -1.750967 & 0.1054 \\
HOMALE SELF EMPLOYMENT(-1) & -0.17877 & 0.056164 & -3.18302 & 0.0079 \\
D(HOMALE SELF EMPLOYMENT) & -0.288442 & 0.038698 & -7.453573 & 0.0000 \\
D(HOSERVICES) & 0.173774 & 0.088385 & 1.966115 & 0.0729 \\
D(ESGROWTH) & -0.164179 & 0.056065 & -2.928362 & 0.0126 \\
D(GUAGROWTH) & -0.182274 & 0.073218 & -2.489474 & 0.0285 \\
CRGROWTH(-1) & -0.150818 & 0.0517 & -2.917194 & 0.0129 \\
C & 11.5241 & 3.392579 & 3.396855 & 0.0053 \\
R2 & 0.799704 & & & \\
\hline
\end{tabular}

The long term equations are shown on Table 4. The coefficients of these equations are obtained dividing the coefficients of the respective variable by the coefficient of the youth unemployment variable lagged one year.

Table 4. Long-term equations of female and male youth unemployment

\begin{aligned} & \hline Female youth unemployment rate $= 1.1901$ HOservices -0.3592 HOExports -0.5518 HORemittances -1.265 HOFemale self employment \\ &-0.5252 ESGrowth -0.4723 IGrowth \\ & \hline Male youth unemployment rate $=0.1258$ HOCredit -0.1583 HORemittances -0.3074 HOMale self-employment -0.2593 CRGrowth \end{aligned}

These equations show that in the long run the rates of youth unemployment are subject to the behavior of various national and international variables, and thus an approach based on Okun's law would lack precision. The results constitute evidence of the importance of Central American integration in the Central American countries' labor markets.

\subsection{Youth Unemployment and Economic Growth}

The impact of youth unemployment on economic growth is analyzed using the expression for GDP per capita, $\mathrm{Pib} / \mathrm{P}$ :

$$
(P i b / P)=(P i b / L) x(L / P)
$$

Where Pib is national GDP, $\mathrm{P}$ is the total population of the country and $\mathrm{L}$ is the dimension of the population that is employed, so $\mathrm{Pib} / \mathrm{L}$ is labor productivity, and $\mathrm{L} / \mathrm{P}$ is the ratio of employed population to the total population.

An equation for the growth rate of GDP per capita is the following:

$$
\begin{gathered}
\text { GrowthGDPpc }=a+b \text { Growth Productivity }+c \text { Growth Femaleemployment / population }+d \text { Growth Male } \\
\text { employment/population }
\end{gathered}
$$

The estimation of this equation is shown in table 5 as equation (1), where it can be observed that all the coefficients are positive and significant. The largest coefficient corresponds to productivity growth (1.0092), 
followed by growth in male employment (0.6468), and female employment (0.3708).

Its valid to assume that when a young person finds employment after a period of unemployment, she or he would have lost skills as a result of the time they were unemployed. For this reason, as well as for working in the informal sector, and because of the accumulated psychological "scars" of being unemployed, when aggregating the experiences of the youth who were unemployed and who have again obtained employment, the resulting aggregate supply of labor may lack the skills, knowledge, and abilities required to increase national labor productivity.

In other words, the experience of youth unemployment can lead to generating, after several years, a labor supply made up of workers who lack good education and skills, who dropped out of school, and who carry the psychological consequences of having been unemployed.

Caceres (2013) has shown that in Latin America labor productivity is negatively associated with informality. It is observed in equations (2) and (3) of Table 5, where labor productivity is the dependent variable, that the female and male youth unemployment rates with lags of 8 and 14 years respectively, have negative and significant coefficients. This means that past experiences of youth unemployment are negatively associated with the growth of labor productivity; youth unemployment in the present is manifested in the future in the drop in labor productivity.

With respect to the other determinant of GDP per capita, the growth of the ratio of employment of people over 15 years of age to the population, it is observed in equations (4) and (5) of Table 5, that the female and male youth unemployment rates have negative and significant coefficients with lags of 16 and 15 years respectively (Note 3). This means that youth unemployment gives rise to decreases in the ratios of employment to population, and thus contributes to economic stagnation.

The ratios of employment to population corresponding to the segments over 15 years of age have decreased since the early 1990s; the decline is particularly marked in the cases of the youth employment to population ratios, as can be seen in Figure 9.

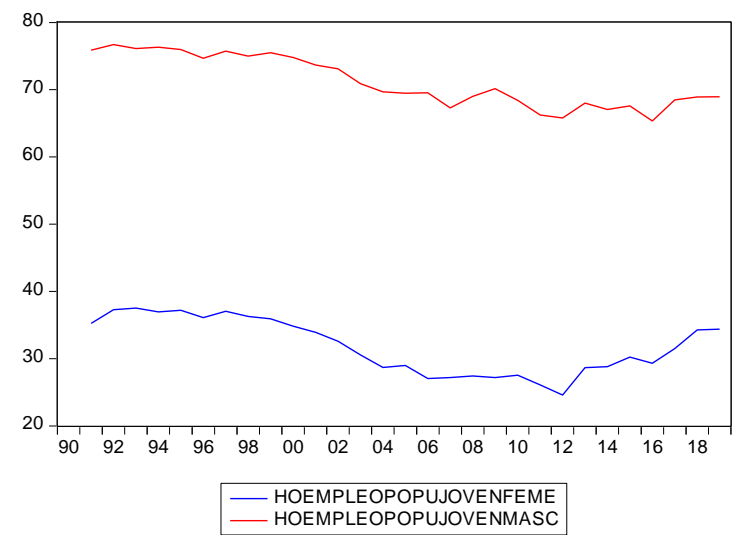

Figure 9. Ratios of female and male youth employment to population

In developed countries the employment to population ratios tend to fall due to the aging of the population. Figure 9 shows that the ratios of youth employment to population look typical of an elderly population; it could be deduced that Honduran youth suffer from "premature aging" and that they tend to "disappear" from their participation in the labor market.

Equation (1) of Table 4 was again estimated using the ratios of female and male youth employment to population, instead of the ratios of total aggregate employment. The estimated equation is shown in Table 4 as equation (6). It can be seen that all the coefficients are positive and significant.

Given that youth unemployment decreases labor productivity and the employment to population ratio, it can be expected that it will also decrease the growth of per capita GDP. Equations (7) and (8) show that female and male youth unemployment rates, both with lags of 14 years, have negative impacts on per capita economic growth. That is, current youth unemployment tends to undermine future economic dynamism.

A point that has to be stressed is that the contribution of the growth of the ratio of male employment to population will likely be negative, given that its ratio is negative as can be seen on table 1 , so economic growth depends on the growth of the ratio of female employment to population and on productivity. 
It has to be stressed that the average values to the growth of the ratios of female and male youth employment to population are negative, as shown on Table 1; this result must be a source of preoccupation to policymakers given that youth should be providing their most distinctive contributions to Honduras' development, but, on the contrary, youth contribution is negative. These results highlight the devastating consequences of youth unemployment, Neets and emigration on national development.

Table 5. Economic growth, productivity and youth unemployment**

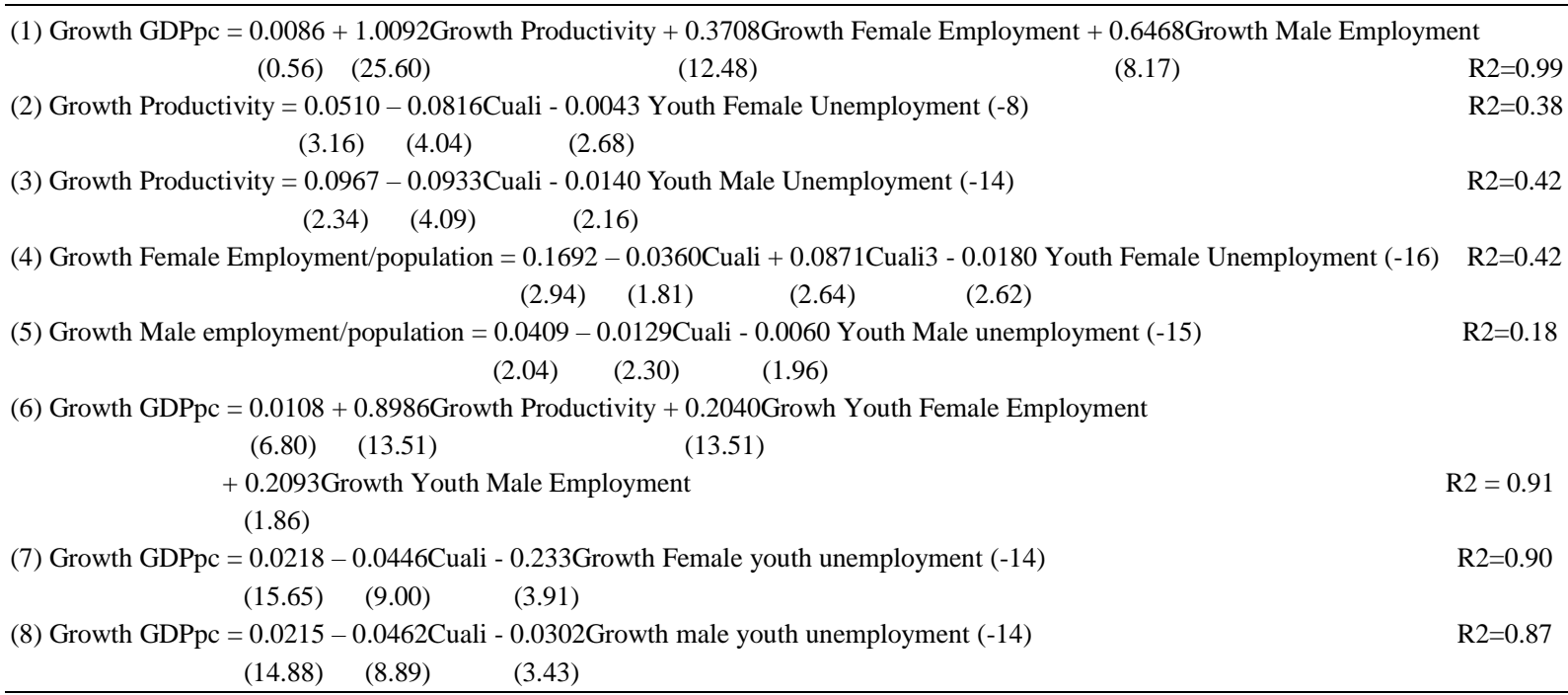

Note. ** In equation (4) cuali3 is a qualitative variable that takes the value of unity in the 2012-2018 periodo.

These results show that youth unemployment, in addition to causing "scars" of various kinds that disrupt young people's lives, also disrupts productivity, labor supply and economic growth, and therefore the population in general.

The point that should be emphasized is the evidence presented by Mckinsley (2017) that in the period 1990-2005, Latin America's labor productivity remained constant or decreased, and that the per capita economic growth experienced in that period, of 2.0 percent, is explained by the growth of 2.6 percent of the employment to population ratio. These authors warn that the growth rate of the employment ratio is going to decrease in the future as a consequence of the aging of the population, and that countries must make great efforts to increase labor productivity and to counteract the fall in employment.

What is observed in Honduras is that both productivity and the employment ratio have been decreasing for several years. The prevailing task in Honduras is to carry out great efforts to recover production and productivity, and also to increase the employment to population ratio, which demands the reduction of youth unemployment.

\subsection{Effects from the Other Central American Countries}

Given the role that economic growth in the other Central American countries exert on reducing youth unemployment in Honduras, as observed in Tables 2 and 3, and given that youth unemployment decreases labor productivity, it can be argued that the economic growth rates of the other Central American countries will have positive effects on Honduras' labor productivity and economic growth. Table 6 presents equations that express the growth of both Honduras' labor productivity and per capita economic growth in terms of variables of the other Central American countries.

In equation (1) the dependent variable is the growth of labor productivity; it is observed that the economic growth rate of El Salvador (ESGrowth), has a positive and significant coefficient, indicating that it contributes to increasing Honduras' labor productivity, by its role in reducing Honduran youth unemployment. The other independent variable, the ratio of exports to GDP, HOExports, also shows a positive and significant coefficient.

A similar result is observed in equation (2) of Table 6, which shows that the coefficient of the economic growth rate of Nicaragua, with a lag of 1 year, NIGrowth(-1), is positive and significant. The coefficient of HoExports is significant and positive, while that of HOServices is negative and significant, highlighting the negative role of the services sector on labor productivity.

Equation (3) expresses the growth rate of Honduras' per capita GDP in terms of El Salvador's economic growth 
rate and the ratio of its remittances to its GDP, ESRemittances, and the ratio of Honduran exports to its GDP. The coefficients of the two El Salvador's variables are positive and significant, that is, they drive the economic dynamism of Honduras, as does the other independent variable, HOExports.

Given that the percentages of female and male Neets decrease as the ratios of youth employment to population increase, as observed in Figures 11 and 12, and given that the economic growth rates of the other Central American contribute to the reduction of Honduras' youth unemployment rates, it follows that the percentage of male Neets will fall with the increase of the economic growth rate of Nicaragua, as shown on equation (4). The other variables, the economic growth rate of Honduras with a lag of 2 years, and Honduran exports, also have negative and significant coefficients.

These equations imply that in an economic integration scheme such as the Central American one, the labor productivity of a member country is determined by the behavior of national and of the other member countries variables, giving rise to the generation of regional productivity externalities. Likewise, the drop in the percentage of Honduran male Neets as a result of Nicaragua's economic dynamism indicates that there is a social dividend resulting from economic integration, which can be viewed as a regional social externality. These results have not been studied in the theory of economic integration and highlight the convenience of combating Central America's youth unemployment problems through a regional approach.

The neoclassical theory of international trade maintains that economic integration is "inefficient" since it entails losses in "welfare". What the equations presented above indicate is that economic integration between developing countries that export and import manufactured products from each other, as in Central America, is efficient since it gives rise to social and productivity externalities, which would not be obtained with unilateral opening. The implication is that more and more economic integration between developing countries is needed.

Table 6. Determinants of labor productivity and economic growth

\begin{tabular}{|c|c|c|}
\hline Equation number: & & \\
\hline (1) GrowthProductivity $=-0.1247+0.006$ & th +0.0023 HOExports & $\mathrm{R} 2=0.31$ \\
\hline (3.47) (2.61) & $(3.49)$ & \\
\hline (2) GrowthProductivity $=0.1902+0.0046$ & $h(-1))+0.0032$ HOExports -0.0061 HOServices & $\mathrm{R} 2=0.68$ \\
\hline $\begin{array}{r}(3.47) \quad(2.61) \\
\text { (3) Growth GDPpc }=-2.1590+0.9172 \mathrm{ES}\end{array}$ & $\begin{array}{c}(4.93) \\
0.0716 \text { ESRemittances }+0.0093 \text { HOExports }\end{array}$ & $\mathrm{R} 2=0.99$ \\
\hline$(7.85)$ & $(7.89)$ & \\
\hline (4) Male Neet $=20.0134-0.2665$ NIGrow & 4383 HOGrowth (-2) - 0.1213HOExports & $\mathrm{R} 2=0.49$ \\
\hline$(8.77)$ & $(4.18)$ & \\
\hline
\end{tabular}

\subsection{Role of the Neets}

The explanation for the decrease of the ratios of youth employment to population can lie, in part, in the decisions made by young persons to enter the situation of youth who neither study nor work, that is, to become Neets. Figures 10 and 11, constructed with 2008-2018 data from Honduras, show that as the percentages of female and male Neets increase, the ratios of female and male youth employment to population tend to fall.

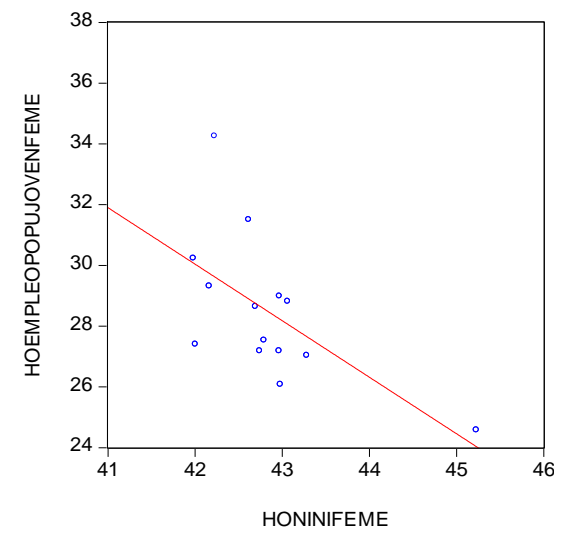

Figure 10. Percentage of female Neets(honinifeme) and female youth employment to population ratio (hoempleopopujovenfeme)

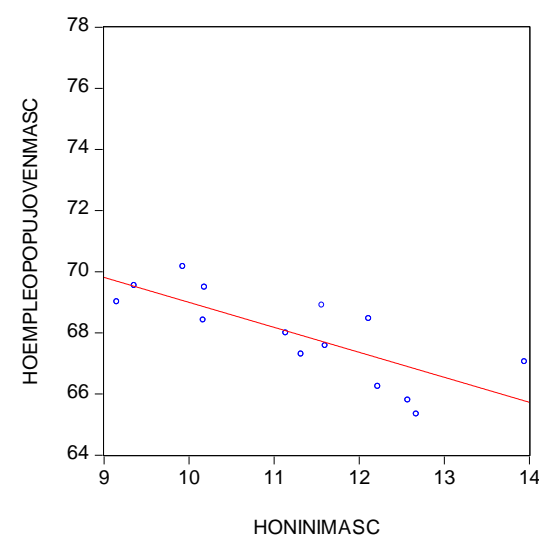

Figure 11. Percentage of male Neets (honinimasc) and the ratio of male youth employment to population (hoempleopopujovenmasc) 
This can explain the case of youth "disappeared" from employment. It should be emphasized that the employment to population ratio is a determinant of GDP per capita; given that the Neets population reduces this ratio, it can be deduced that Neets fuel the stagnation tendencies of the Honduran economy.

It should be noted that Cárdenas, de Hoyos, and Szekely (2016) have reported that in the Latin American countries, on average only 86 percent of female Neets rejoin the labor market; the percentage for male Neets is 40 percent. This means that Neets can cause persistent losses of economic growth.

Figures 12 and 13 show that there are positive relationships between the female and male youth unemployment rates, lagged 8 and 11 years respectively, and the percentages of female and male Neets.

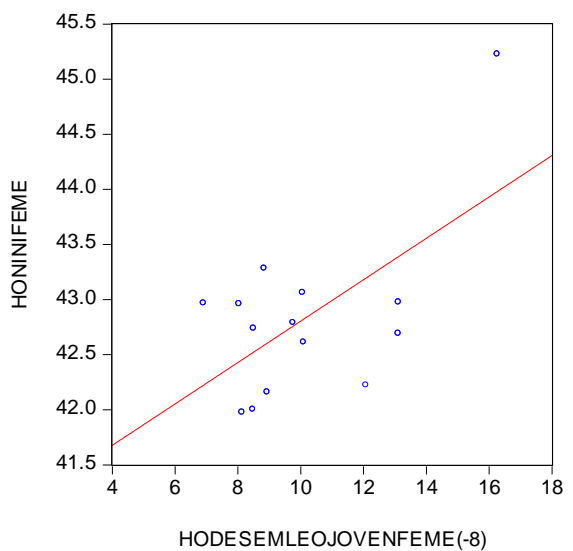

Figure 12. Female youth unemployment rate lagged 8 years and the percentage of female Neet

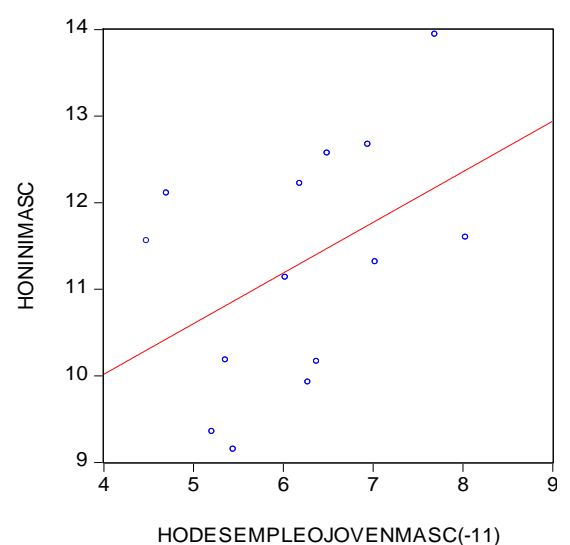

Figure 13. Male youth unemployment rate lagged 11 years and percentage of male Neets

In other words, youth unemployment serves as an "incubator" for Neets, and thus draws potential workers from the labor market, with negative implications for economic growth.

It should be noted that the national percentages of Neets are important determinants of the homicide rate in Latin American countries. Based on a sample of 2010 data from 13 Latin American countries (Note 4), Figure 14 shows that as the percentage of female Neets increases, the number of homicides per 100,00 people, (homicidios), also increase.

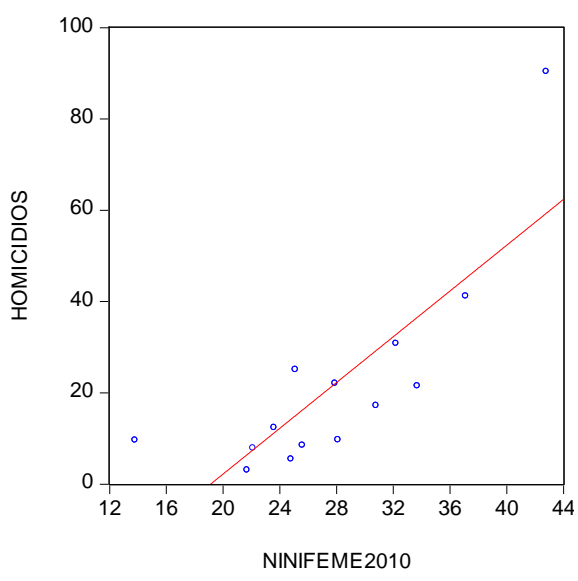

Figure 14. Percentage of female Neets and the number of homicides / 100,000 people

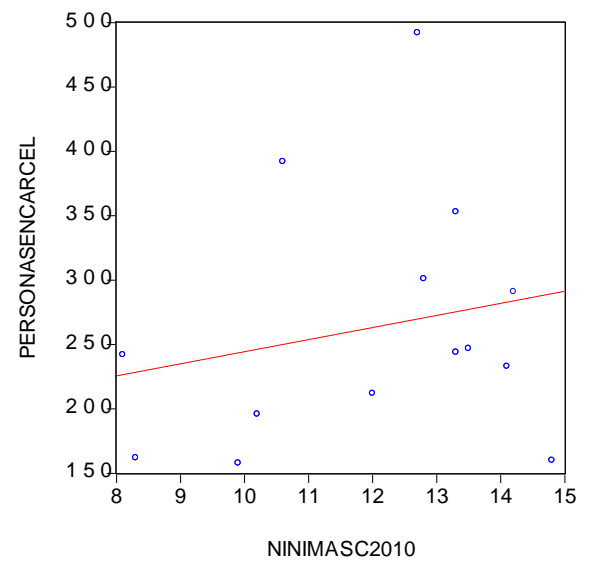

Figure 15. Percentage of male Neets and the number of people of both sexes incarcerated per 100,000 inhabitants, (personasencarcel), average 2004-2018

There is also an association between the percentage of male Neets and the number of people who are in prison, as shown in Figure 15.

The implication is that by being an "incubator" of Neets, youth unemployment gives rise to homicides and consequently is associated with the number of incarcerated persons. Thus, measures taken to combat youth unemployment would lead to the reduction of violence. 
There is another angle to analyze the implications resulting from Neets, which is its association with irregular emigration, and hence with remittances. Figure 16 shows that there exists a positive association between the percentage of female Neets and remittances as a percentage of GDP, which means that remittances and irregular emigration, are originated in youth unemployment and in being in a situation of Neet. Thus, it is valid to argue that the prevention of youth unemployment would lead to reduce irregular emigation.

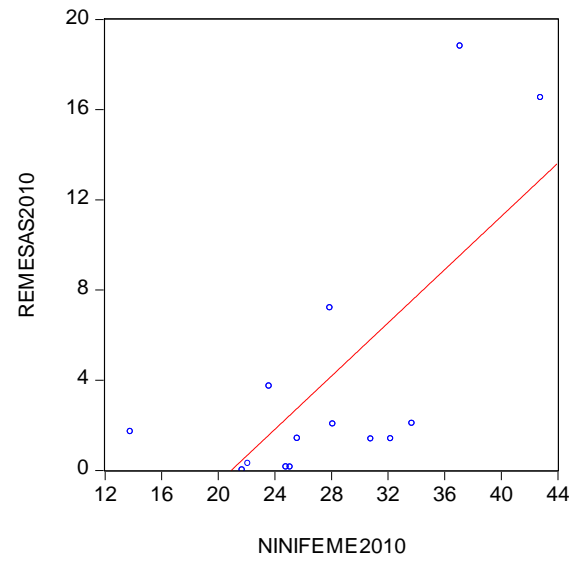

Figure 16. Percentage of neets and remittances as percentage of GDP, (Remesas, 2010)

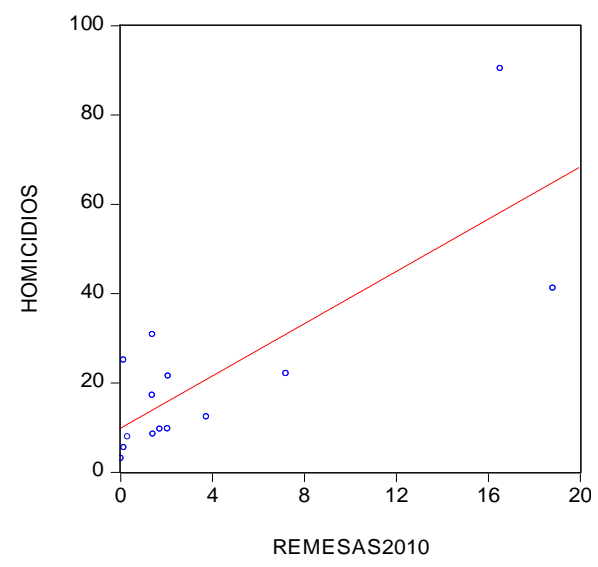

Figure 17. Remittances and homicides per 100,000 inhabitants

The number of homicides is part of the same structure of exclusion which is substantiated by the relationship between remittances and the number of homicides per 100,000 inhabitants shown on Figure 17.

This uncovers the prevalence of a common situation that exists behind youth unemployment, Neets, and emigration, which is the low levels of social spending.

The existence of a common cause to these problems is sustained by the relationship between the Human Opportunity Index, IOH, and the percenatge of female ninis, shown on Figure 18. The IOH was developed by the World Bank (Molinas et al, 2011) and measures the degree in which girls and boys in a given country have acces to the services of education, electricity, potable water, housing, and finishing the sixth grade in the reglamentary period, independently of their geoFigureical area of residence and of their parents, income. As such the IOH is a measure of social mobility.

It should be mentioned that Honduras, and Guatemala and El Salvador have the lowest human opportunity indexes in Latin America and the highest number of homicides per 100,000 persons.

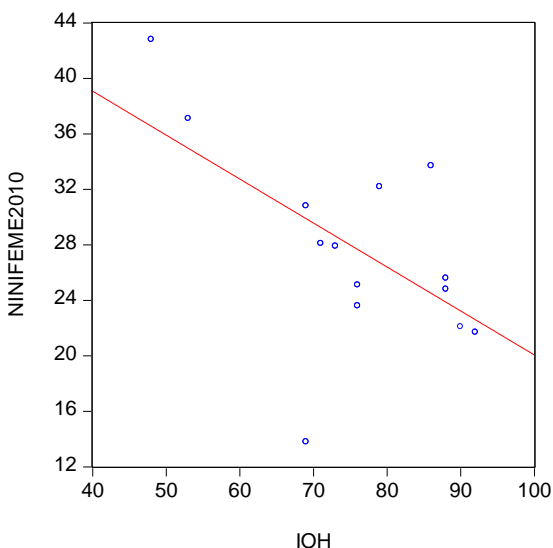

Figure 18. Index of human opportunity and percentage of female neets

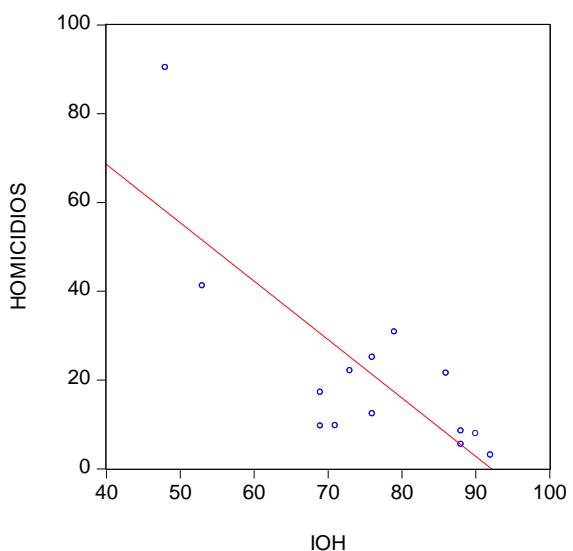

Figure 19. Human Opportunity Index and number of homicides

The IOH has negative associations with the numbr of homicides (Figure 19), and with the number of incarcerated persons (Figure 20), which implies that the prevention of violence in Latin America demands increasing social investments that would improve social mobility. 


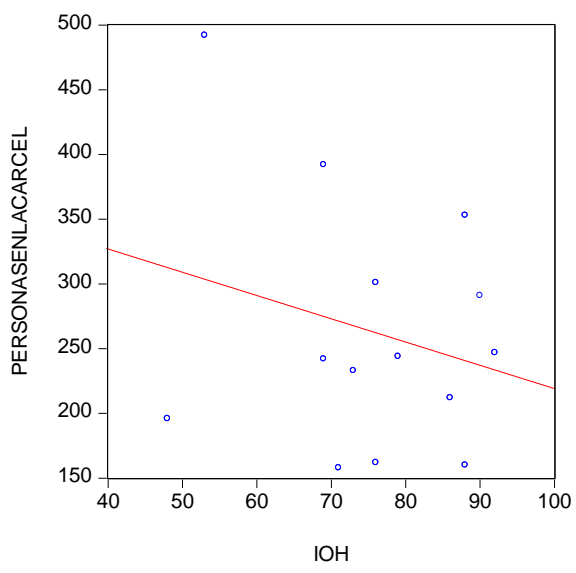

Figure 20. Human opportunity index and number of incarcerated persons

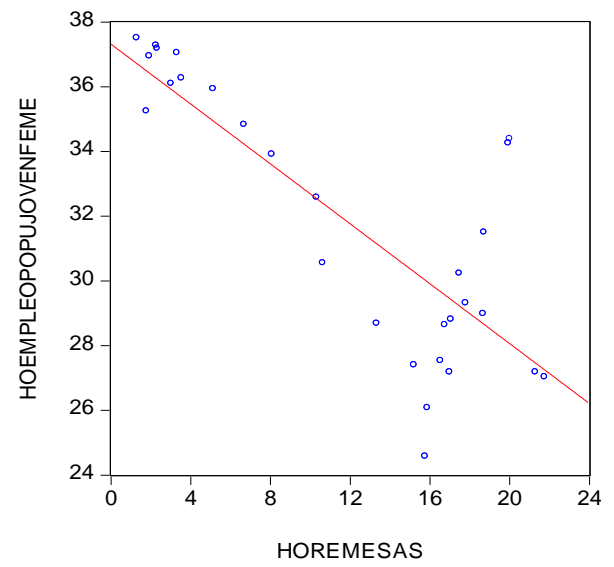

Figure 21. Remittances and ratio of female youth employment to polulation

Moreover, there are no estatistics available on the number of youth and older persons who have emigrated from Honduras, but as was indicated, remittances can be used as an approximation, under the assumption that the more people have emigrated larger will be the amounts of remittances received by Honduras. It can be seen on Figures 21 and 22 that as remittances have increased the ratios of female and male youth employment to population has decreased, with negative consequences on economic growth. This explains the case of "missing" youth in Honduras, a topic that has not been analyzed in the literature.

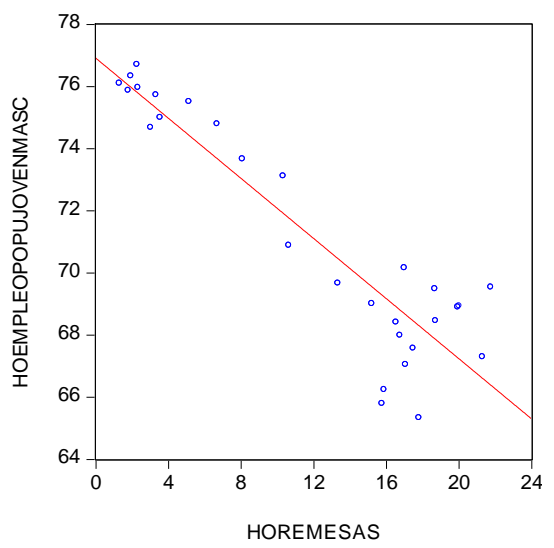

Figure 22. Remittances and ratio of male youth employment to population

This shows an additional channel through which youth unemployment exerts negative impacts on economic growth, which is its positive impact on inducing youth to emigrate, which lowers the ratio of employment to population.

There is an irony in the depressing effect that emigration and remittances exert on Honduras' economic growth, given the positive repercussions that migration have on developed countries that receive emigrants as has been shown by a recent IMF paper (Jaumotte, Koloskova, \& Saxena, 2016), which showed that migrants give rise to increases of two per cent in additional GDP per capita growth in receiving developed countries mainly through increases in productivity.

\subsection{Role of Education}

At this point the relevant question is related to the measures that should be taken in Honduras to reverse the declining trends in economic growth and youth employment.

Improving the quality of education can be a valuable economic policy, since it is negatively associated with the school dropout rate, with the fertility rate of adolescents, and with the percentages of Neets, and has a positive association with the rate of economic growth (Cáceres, 2018).

Honduras, as well as Nicaragua and Guatemala, have the lowest results in international tests of quality of 
education, measured as the scores in the reading and mathematics tests in third and sixth grade, as observed in the results from the Third Regional Quality Assessment of Education, which took place in 2013 (TERCE, 2016) (Note 5). An important point that emerges from the TERCE is that the scores that measure the quality of education increase as public spending on education as a percentage of GDP increases in the respective countries (Figure 23).

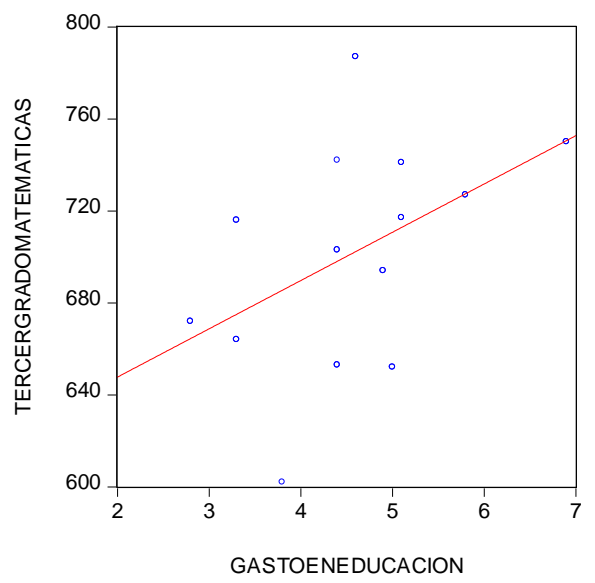

Figure 23. Expenditure on education (gastoeneducacion) and mathematics scores in third grade (tercergradomatematicas)

The importance of the quality of education is that the economic growth of the Latin American countries is largely determined by the quality of their education, as has been shown by Caceres (2018) and Hanushek and Woessmann (2009). It can be observed in Figure 24 that as the results in sixth-grade mathematics increase, the per capita growth rates of the countries also increase.

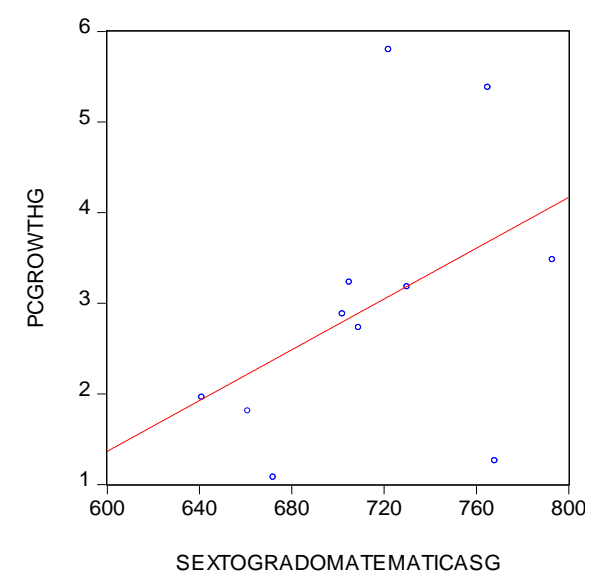

Figure 24. Results of mathematics in sixth grade and per capita economic growth (pcgrowthg)

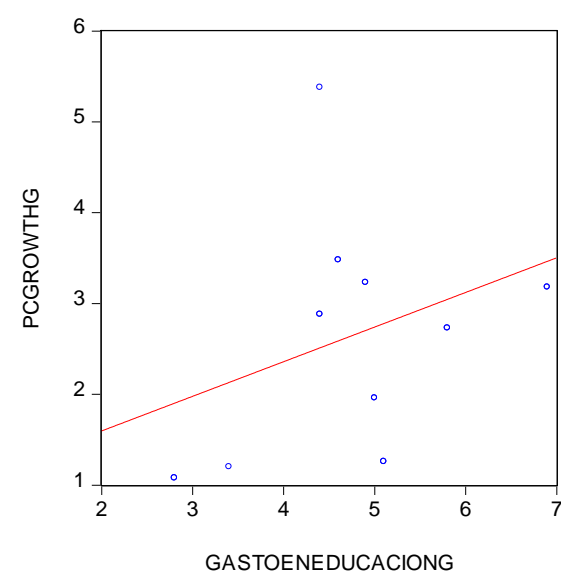

Figure 25. Expenditure on education as a percentage of GDP and economic growth per capita.

Given that the quality of education increases with public spending on education as a percentage of GDP (Caceres, 2018), increasing spending on education represents a means to boost economic growth. This can be seen in Figure 25 for a sample of Latin American countries.

In other words, countries that invest more in education have higher economic growth rates than countries that spend little. It should be mentioned that public spending on education as a percentage of GDP has a negative association with the percentage of female Neets in the Latin American countries, as can be seen in Figure 26. 


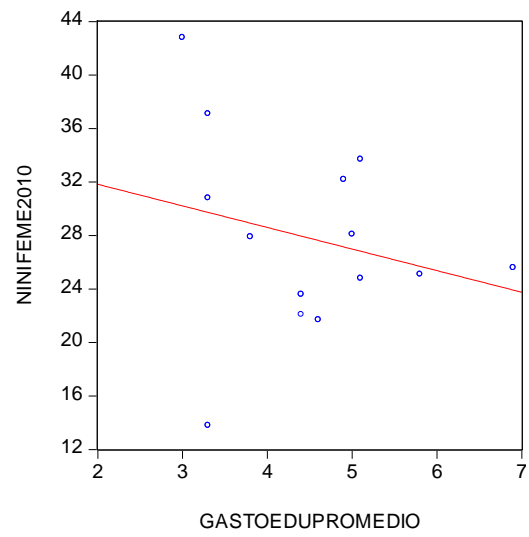

Figure 26. Public spending on education as a percentage of GDP and the percentage of female NEET

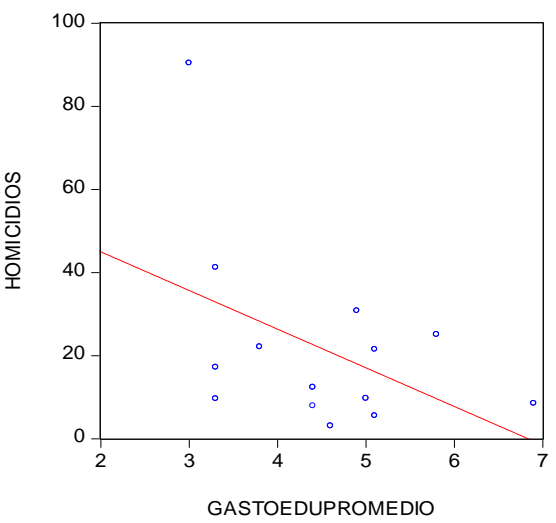

Figure 27. Education expenditures and number of homicides

Particular interest resides in the relationship between education expenditures and the number of homicides, shown on Figure 27, which means that violence can be curtailed thorugh investing in education.

This indicates that by increasing spending on education it can be possible to obtain goals that have been elusive in the past, such as increases in the rate of economic growth and productivity, in exports, and private investment (Cáceres, 2018). In other words, through education, answers can be given to problems that plague the Honduran economy and society.

Reference must be made to the evidence that shows that people with low levels of education are the ones who tend to suffer from unemployment in a more accentuated way.The Washington Post newspaper of May 10, 2020, in an article on the ravages of the Covid19 in the United States, reported that the unemployment rates of people who had not finished secondary education ("high school"), was 21.2 percent, that of people who had a high school education was 17.3 percent, and of people who had a BS degree, it was 8.4 percent.

In other words, as the level of education of people increases, the incidence of unemployment tends to fall, that is, education "protects" individuals from unemployment.

Askenazy, Chevalier, and Erhrl (2015) have reported that the results of Okun-type equations estimated for the US and the EU, and with data from different groups of people differentiated by levels of education, which showed that the groups with higher levels of education had Okun coefficients equal to zero, which means that for people with high levels of education, their jobs were not susceptible to the ups and downs of the economy; for those with medium and low levels of education the estimated equations showed the existence of significant Okun coefficients.

The implication is that fighting youth unemployment involves making great efforts in education, particularly increasing public sector expenditures in education.

The categorical attention to education (and health) as the national priority should be an important part of the economic recovery after the crisis of the Covid19 pandemic. There is no other measure that can be so effective to impart dynamism to the economy and to prevent violence and emigration.

In this context, reference must be made to the evidence from Mexico that as a result of the economic recession of 2008-2009 the resulting growth in unemployment led to increases in school dropout rates, which led to increases in the Neet population and violence (de Hoyos, Gutiérrez Fierros, \& Vargas, 2016).

The implication is that the increases in unemployment which have occurred in Honduras and in the other Central American countries as a result of the Covid pandemic, will have to be confronted with decisive measures to avoid increases in violence. In this sense, Cunningham and Bagby (2010) have presented evidence for Mexico and Chile that the quality of education prevents school dropout, prevents young people from engaging in drug use and violence. Hence the importance of promoting the quality of education as the most urgent response to the unemployment crisis resulting from the pandemic.

\subsection{Education and Economic Integration}

This section demonstrates that the interdependence existing in an economic integration program, as the one existing in Central America, gives rise to an interdependence in the member countries' percentages of Neets and of homicide rates, which is discussed in Figure 28. 
In the case of country 1, quadrant (1) shows the positive association between public sector expenditure on education, Edu1, and the quality of education, Calidad1. In quadrant (2) it is observed that the increase in the quality of education leads to a decrease in the percentage of Neets, Neet1. Quadrant (3) shows the negative association between the percentage of Neets and country 1's rate of economic growth, Growth1. With quadrants (1) and (3) a Figure is obtained in quadrant (4) that shows the relationship between country 1's expenditure in education and its rate of economic growth.

Given the increase in the rate of country 1 economic growth, country 1 will import more goods from country 2 , so that country 2 exports to country 1 , x2, will increase. This relationship is shown on quadrant (5). Given the increase in its exports, country 2 will experience an increase in its rate of economic growth, Growth2, as shown on quadrant (6). Using the 45 degrees line shown on quadrant (7) a Figure is obtained in quadrant (8) depicting the positive association between countries 1 and 2 growth rates. This means that increasing country's expenditures in education can give rise to to synchronous rates of economic growth in the integrating area, which ensures that all countries benefit from the integration scheme. This has implications on the distribution of costs and benefits from integration.

In quadrant (9) a line is constructed that reveals that as country 1's education expenditures increase, country 2's rate of economic growth increases. Quadrant (10) shows that country 1's percentage of Neets have a negative association with country 2's rate of economic growth, which means that Neets exert negative spillover effects across the countries members of an integration program, and that here may exist clusters of low social expenditure, low education quality, economic stagnation, percentage of Neets, irregular emigration, and violence. Or there may occur virtuous clusters activated by increasing social expenditures.

Quadrant (11) shows the negative relationship between country 2's rate of economic growth and the percentage of Neets. Using quadrants (10) and (11) a Figure is obtained in quadrant (12) that depicts the positive association between countries' 1 and 2 Neets. Quadrants (13) and (14) show the associations between both countries' Neets and their respective homicide rates; with these 2 quadrants a Figure is obtained in quadrant (15) showing the positive relationship between Homicides1 and Homicides2, which imply the existence of interdependence in violence.

Quadrants (16) shows that countryl's homicide rate fall with the increase in countryl's education expenditures, and with country 2's rate of economic growth.

The Figure above shows the existence of interdependence in economic growth, in the percentages of Neets and homicides. The implication is that youth unemployment, percentages of Neets and violence are regional phenomena and their solution demands a regional approach. A purely national response to these problems would be inefficient because it would not take advantage of positive spillovers impacts across countries. It should be observed that these benefits would not be obtained by unilateral opening, which in reality its main repercussion has been a flood of imports that displaced national production. Another implication is the importance of strengthening Central American economic integration.

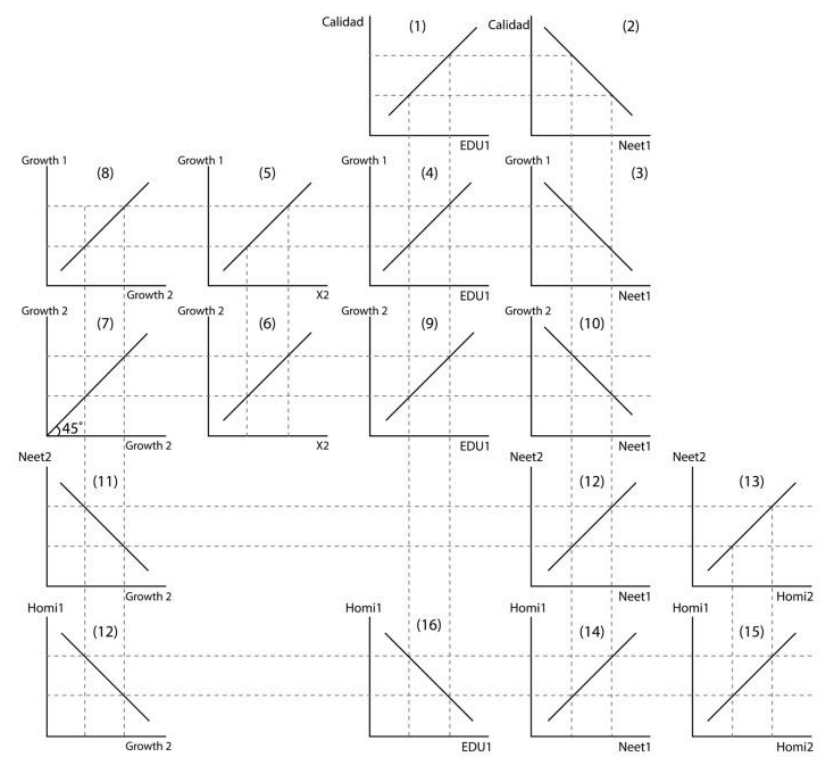

Figure 28. Education and economic integration 


\section{Discussion}

\subsection{Honduran Youth Agenda}

This section stresses the importance for Honduran and other Central American countries that resides in the design and execution of a Youth Agenda would have. The purpose of the Agenda would be to promote increases in the national budget allocations to areas associated with the well being of youth. It would be structured by civil society organizations, students in secondary, technical and higher education, and young people interested in participating. The Agenda would comprise the areas that young people demand that receive priority attention from governments, the private sector, and the of society in general, with the objective that such priority is reflected in increased monetary allocations in the national budget.

This exercise would help to underline the needs and demands of the youth in areas that determine its future and would contribute to maintaining a dialogue on the urgency of serving youth with the highest priority.

This exercise would also represent a challenge to Honduran society's capacity for reaching consensus.

It should be added that Bruno et al. (2014) have shown that the percentages of Neets are persistent, so that audacious measures have to be promoted.

An outline of a prototype of the Honduran Youth Agenda is presented below on table 7.

Table 7. Honduran Youth Agenda

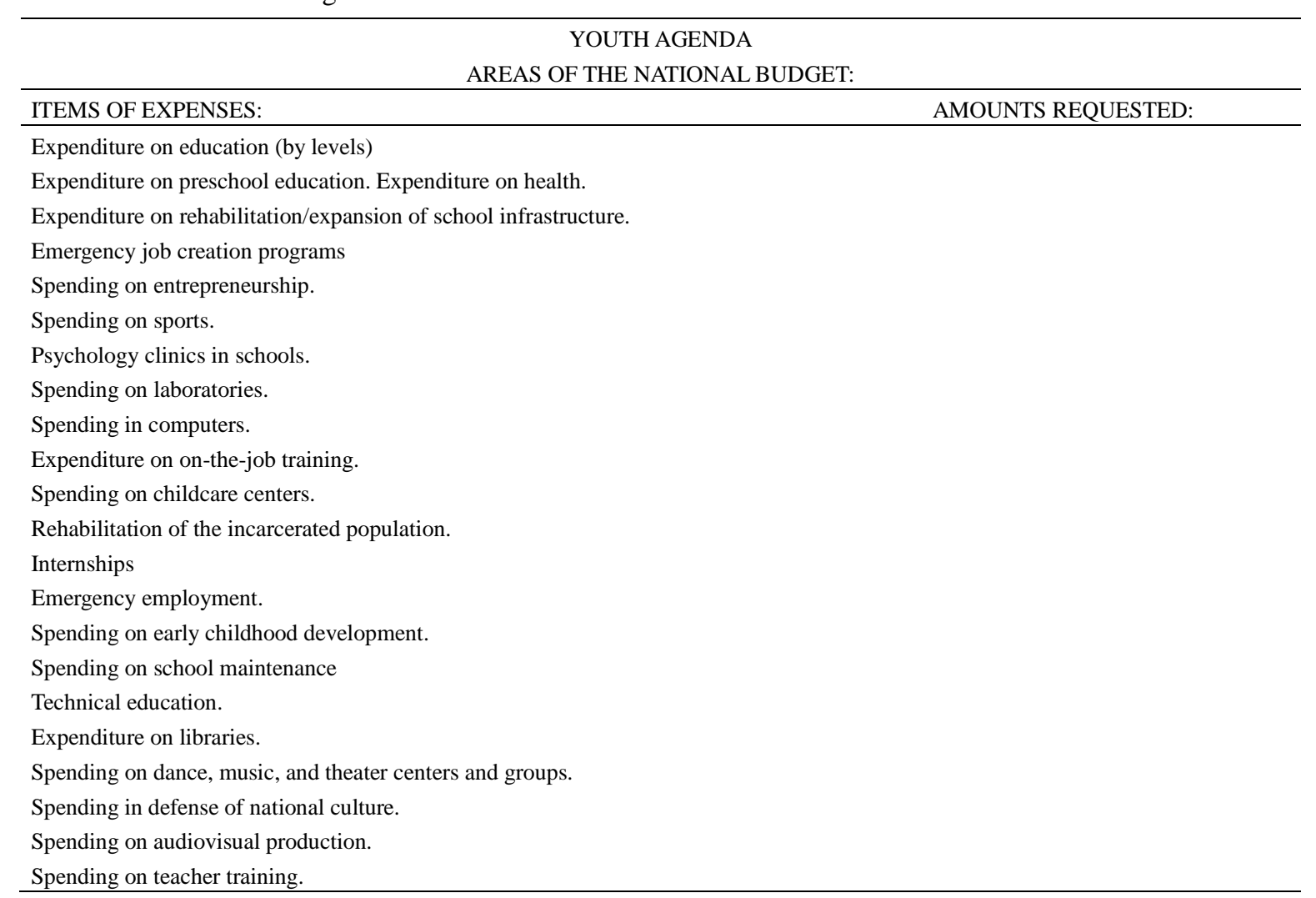

This mechanism would be developed mainly by young people who, in turn, would negotiate it with the corresponding authorities. The main argument is that the budget allocations included in the Youth Agenda are associated with economic development, and that there is a great debt that society owes to the youth and now is the time to remedy the injuries.

But Honduras' youth have to mobilize and present their demands, must play a leading role in determining their future, and convince the authorities that what the Agenda includes are accurate measures validated by the economic history of the now developed countries, and therefore are for the benefit of Honduran society (Be strong and bold, Deuteronomy, 31, 6).

If youth do not demand categorical attention to their needs, they could have the same fate as that of past 
generations: unemployment, emigration, caravans, violence, cemetery.

Based on the relationships shown on previous sections, it can be deduced that increasing social expenditures would lead to falls in self employment, in Neets, homicides, number of persons who are incarcerated, irregular emigration, remittances, would lead too to increasing the ratio of employed persons to population, and hence to dynamic economic growth. The main obstacle has been the reluctance to increase tax revenues resulting from the opposition from economic elites, but this opposition has backfired as the result has been violence and economic stagnation. This is a situation that can be reverted by implementing the Youth Agenda.

Related to the Agenda, it would be necessary to structure a series of progress indicators to know if the budget allocations are being carried out as requested, and to maintain the insistence that youth should receive the maximum attention in the budget allocations, and to know the impacts and results from budget execution.

At the end of the fiscal year a comparison would be made of the budget allocated and what was spent. Also, the trajectory of the impact indicators associated to the action of the public sector and its budgetary expenditures would be analyzed.

For those purposes, a monitoring and evaluation sheet could be the following (table 8):

Table 8. Monitoring the Youth Agenda (indicators)

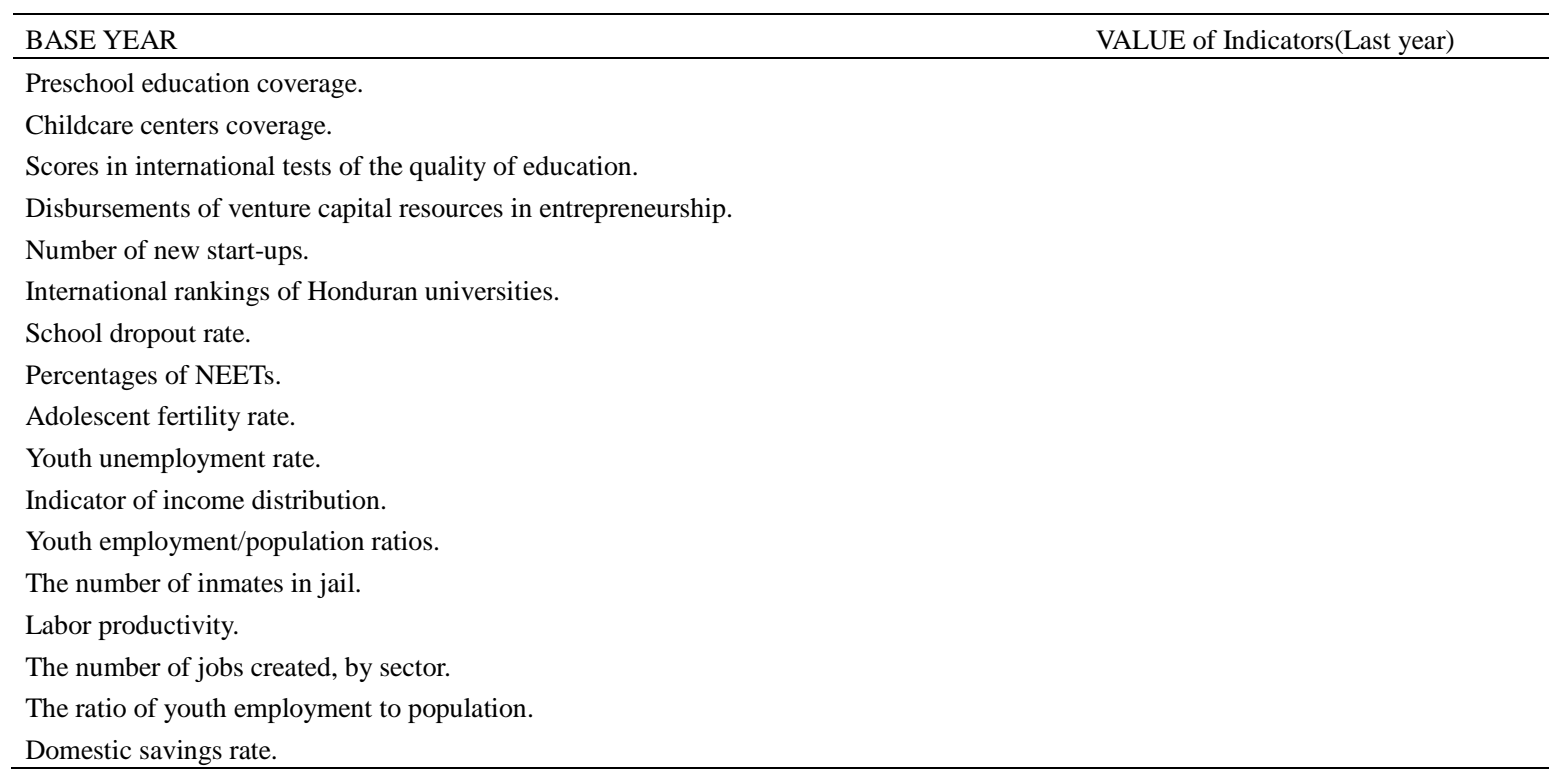

\section{Conclusions}

From this paper it can be deduced that many variables determine the youth unemployment rates in Honduras, such as credit, exports, and female and male self-employment rates; likewise, variables of the other Central American countries, such as their economic growth rates and their remittances, have impact on Honduras' youth unemployment. Therefore, basing the analysis of unemployment exclusively on the trajectory of economic growth, as established by Okun's law, could lead to inaccurate results. Youth unemployment was also found to undermine economic growth and productivity, and to contribute to the growth in informality and violence. A result that deserves special attention is that the ratio of male employment to population, as well as the ratios of female and male employment to population have been declining and have negative average values, which show the severity of the youth unemployment and emigration problems in Honduras.

A valuable response to remedy these effects would consist of an extraordinary support to improve the quality of education.

The great restriction to these purposes is the fiscal weakness of the state, especially after the pandemic. But this is not a situation that cannot be solved; a solution must be found on the side of the increase in tax revenues to decisively address the expenses that are of utmost importance for the future of the country, as well as by decreasing superfluous expenditures. In this endeavor special attention should be given to taxing the Honduran nationals" deposits in offshore "tax heavens"

It is necessary to exercise a true fiscal responsibility, understood as responding categorically to the education and 
health needs of the population, and to the imperative of imparting dynamism to the economy after the pandemic.

In this context reference must be made to ECLAC (2019) research that has presented tax evasion figures for the Latin American countries, which place it for the entire region at 6.8 percent of regional GDP, that is, an amount of 350 billion dollars. Therefore, public finances can improve through the fight against tax evasion, which acquires special importance given the financial needs of the state as a result of the pandemic crisis, and the urgent need to recover and rehabilitate the economy. ECLAC (2018) has indicated that in Latin America large companies only pay 6 percent of their income as income tax, and that companies whose owners are located in the richest ten percent of the population stratum only pay 4 percent, which is another manifestation of the "culture" of abuse and privilege that exists in the region.

The efforts to reduce tax evasion would include measures related to warnings to taxpayers that auditing efforts will be redoubled and that the number of auditors will be increased; it is also necessary to make the population see the importance of taxes for national development, to establish a pact between taxpayers and the government, in the sense that in exchange for the increased taxes paid, the government will deliver goods and services of value to the population.

This would also include the citizens' discussion of the annual budget project before it is approved by Congress, and, at the end of the fiscal year, the disclosure and discussion of its evaluation, based on a series of performance and transparency indicators, analyzing the divergences between what was programmed and what was executed.

Youth should play an important role in this matter, demanding that the items that determine their well-being, which is the well-being of the country, receive the highest priority in the annual budget

A point that should be stressed is the importance of raising import tariffs so as to reduce imports of luxury goods and those that displace national production and employment, so that good jobs are shielded, and industrial production is boosted as well as agriculture. Honduras has one of the lowest import tariffs in Latin America and has served little purpose, except the loss of good jobs, and the boost to imports that have displaced national production.

Other measures that can be of great value are emergency employment programs. Evaluations carried out by the World Bank (2011) of 46 programs of this nature showed that in all cases the benefits were greater than the costs. The World Bank has reported that rural road construction and maintenance programs can be valuable in creating emergency employment (Schwartz, Andrés, \& Dragoiu, 2009).

Of special importance is to emulate the case of India in the sense that it carried out changes in its constitution to establish the realization of the right to work, stipulating that each citizen has the guarantee that she or he can work a minimum of 180 days a year. The guarantee of the right to work in the case of Honduras should stipulate not only the validity of this right, but the obligation of the public sector to include in the nation's budget the resources destined to to make reality said right.

It must bear in mind the role of the economic activity of the other Central American countries on the behavior of youth unemployment in Honduras. This is an additional argument to establish a mechanism for the coordination of economic and social policies in Central America, as well as to deepen regional integration.

In this sense, a mechanism that could be of value is the design and execution of regional sector investment programs that specify the objectives shared by the countries, the investment goals of each country, and the amounts of national and external financing required. The countries would seek points of tangency in terms of investment areas, objectives, goals, and progress and impact indicators, with the purpose of designing investment programs with a regional vision. These programs should give priority to economic recovery after the Covid 19 pandemic; to rural infrastructure; youth employment, education quality, infrastructure in border areas; eradication of epidemies; science and technology; emergency employment generation, among others.

Of special importance is the agreement by the Central American countries to proceed jointly in areas related to the post-pandemic economic and social environment, which could include joint actions to support the modernization of laboratories and equipment of research, support for the modernization of the different areas of public health; support for the modernization of university courses in public health, infectology and, especially, telemedicine and other applications of technology in medicine.

In the social area, special importance lies in the regional coordination of the countries in the design and implementation of national networks of childcare centers, which would be of value in helping single mothers to return to school and not be condemned to become Neets. Rodgers (1994) showed that the main determinant of the incidence of poverty in single mother heads of household was their low level of education and recommended the creation of networks of low-cost childcare centers, to help them have time to study and increase their skills. 
Special importance lies in the creation of a regional emergency fund capitalized with contributions from Central American countries and the international community, which would serve to respond promptly to the first signs of contagious diseases.

Central American countries should emulate the initiatives taken by European countries in the sense of providing youth with apprenticeships so as to facilitate the transition from school to work. Equally important is the efforts that the Central American countries undertake to design and implement mechanisms that European countries and the US have establish to help the unemployed and at risk youth to obtain employment, such as the Young Persons' Guarantee, the Future Jobs Fund, and CareFirst existing in the United Kingdom; the Young People Act in The Netherlands; as the Work Force Investment Act established in the US (Note 6).

Evidence has been presented by Junakar (1991) that people who experience periods of unemployment tend to die at an earlier age than people who do not have this experience. Since the Universal Declaration of Human Rights is the law of the land in all countries of the Americas, reference must be made to its article 3 establishes the right to live in these terms: Every individual has the right to life, liberty, and security of his person.

Then it follows that there is an obligation of the states that have signed said Declaration to honor such mandate. This gives youth and citizens in general, the basis to demand that their lives not be cut short, that they do not end in a caravan, but rather that they enjoy employment, dignity, and respect for their human rights. Honduras' youth deserve much more than exclusion and death; governments and society must meet their obligations to implement policies that would change youth current destiny, thus complying with Deuteronomy 16, 20: Justice and only Justice, you shall pursue.

\section{References}

Apap, W., \& Gravino, D. (2016). A Sectoral Approach to Okun's Law. Applied Economic Letters, 24, 319-324. https://doi.org/10.1080/13504851.2016.1186789

Azkenazy, P., Chevalier, M., \& Erhel, C. (2015). Okun's Law Differentiated by Education. Centre Pour la Recherche Economie et Ses Applications, Document 1514.

Banerji, A., Lin, H., \& Saksonovs, S. (2015). Youth Unemployment in Advance Europe: Okun's Law and Beyond. International Monetary Fund, Working Paper 15/5. https://doi.org/10.5089/9781498382519.001

Bell, D. N. F., \& Blanchfloer, D. G. (2011). Youth Unemployment in Europe and the United States. IZA workin paper number 5673 .

Berlingieri, F., Bonin, H., \& Sprietsma, M. (2014). Youth Unemployment in Europe. Appraisal and Policy Options. Centre for European Economic Research.

Bruno, G. S. F., Marelli, E., \& Signorelli, M. (2014). The Rise of Neet and Youth Unemployment in the EU Regions after the Crisis. Comparative Economic Studies, 56, 592-615. https://doi.org/10.1057/ces.2014.27

Caceres, L. R. (2013). Self-Employment in Latin America. Journal of Developing Areas, 51.

Caceres, L. R. (2014). Economic Integration and Unemployment in Central America. Journal of Developing Areas, 48, 43-60. https://doi.org/10.1353/jda.2014.0011

Cáceres, L. R. (2018). Hechos Estilizados sobre la Calidad de la Educación en América Latina. Unpublished.

Caporale, G. M., \& Gil-Alana, L. (2014). Youth Unemployment in Europe: Persistence and Macroeconomic Determinants. Comparative Economic Studies, 56, 581-591. https://doi.org/10.1057/ces.2014.29

Cardenas, M., de Hoyos, R., \& Szekely, M. (2015). Out-of-School and Out-of-Work Youth in Latin America: A Persistent Problem in a Decade of Prosperity. Economica, 16.

Cazes, S., Verik, S., \& Al Hussami, A. (2013). Why Did Unemployment Respond so Differently to the Global Financial Crisis Across Countries? Journal of Labor Policy, 2, 2-10. https://doi.org/10.1186/2193-9004-2-10

Chioda, L. (2016). Stop the Violence in Latin America. Washington DC, World Bank.

Choudhry, M. T., Marelli, E., \& Signorelli, M. (2012). Youth Unemployment Rate and Impact of Financial Crisis. International Journal of Manpower, 33, 76-95. https://doi.org/10.1108/01437721211212538

Clark, A., \& Oswald, A. J. (1994). Unhappiness and Unemployment. Economic Journal, 104, 448-559. https://doi.org/10.2307/2234639

Cortes, G. M., Jaimovich, N., \& Siu, H. E. (2018). The "End of Men" and the Rise of Women in the High-Skilled Labor Market. NBER Working Paper 24274. https://doi.org/10.3386/w24274 
Cunningham, W., \& Bagby, E. (2010). Factors that Predispose Youth to Risk in Mexico and Chile. World Bank, Working Paper 5333. https://doi.org/10.1596/1813-9450-5333

Dao, M. C., \& Qian, L. (2017). Finance and Employment in Developing Countries: The Working Capital Channel. IMF Working Paper 17/189. https://doi.org/10.5089/9781484314197.001

De Hoyos, R., Gutierrez Fierros, C., \& Vargas, J. V. (2016). Idle Youth in Mexico. World Bank Working Paper 7558.

De Hoyos, R., Popova, A., \& Rogers, H. (2016). Out of School and Out of Work. A Diagnostic of Neets in Latin America. World Bank Working Paper 7548. https://doi.org/10.1596/1813-9450-7548

Dunsch, S. (2016). Okun's Law and Youth Unemployment in Germany and Poland. International Journal of Management and Economics, 49, 34-57. https://doi.org/10.1515/ijme-2016-0003

ECLAC. (2018). The Inefficiency of Inequality. Santiago de Chile.

ECLAC. (2019). Fiscal Panorama of Latin America, and the Caribbean. Santiago de Chile.

Giuliano, P., \& Spilimbergo, A. (2009). Growing Up in a Recession: Beliefs and the Macroeconomy. NBER Working Paper 15321. https://doi.org/10.3386/w15321

Goldsmith, A. J., \& Darity Jr., W. (1995). The Impact of Labor Force History on Self Steem and its Components Parts, Anxiety, Alienation, and Depression. Journal of Economic Psychology, 17, 183-220. https://doi.org/10.1016/0167-4870(96)00003-7

Gregg, P. (2001). The Impact of Youth Unemployment on Adult Unemployment. Economic Journal, 111, 623-653. https://doi.org/10.1111/1468-0297.00666

Gregg, P., \& Tominey, E. (2004). The Wage Scar from Youth Unemployment. CMPO working paper number 04097.

Hutengs, O., \& Stadtmann, G. (2014). Don’t Trust Anybody Anybody Over 30: Youth Unemployment and Okuns Law in CEE Countries. Bank I Kredyt, 45, 567-580. https://doi.org/10.1057/ces.2014.22

Hutengs, O., \& Stadtmann, G. (2014). Youth and Gender Specific Unemployment and Okun's Law in Scandinavian Countries. European University Viadrina Frankfurt (Oder), Discussion Paper 352.

Jaumotte, F., Koloskova, K., \& Saxena, S. C. (2016). Impacto of Migration on Income Levels in Advanced Economies. International Monetary Fund, Spillover Notes, No. 8.

Johnson, P., \& Reid, H. (2006). Intergenerational Mobility Among the Rich and the Poor: Results from the National Child Development Survey. Oxford Review of Economic Policy, 12, 127-142. https://doi.org/10.1093/oxrep/12.1.127

Junakar, P. N. (991). Unemployment and Mortality in England and Wales: A Preliminary Analysis. Oxford Economic Papers, 43, 305-320. https://doi.org/10.1093/oxfordjournals.oep.a042001

Kahn, L. B. (2008). The Long Term Labor Market Consequences of Graduating from College in a Bad Economy. Labor Economics, 17, 303-316. https://doi.org/10.1016/j.labeco.2009.09.002

Kose, M. A., \& Rebucci, A. (2005). How Might CAFTA Change Macroeconomic Fluctuations in Central America? Lessons from NAFTA. Journal of Asian Economics, 16, 77-104. https://doi.org/10.1016/j.asieco.2004.12.003

Latif, E. (2010). Crisis, Unemployment and Psychological and WellBeing in Canada. Journal of Policy Modeling, 32, 520-530. https://doi.org/10.1016/j.jpolmod.2010.05.010

Mckinsey Global Institute. (2017). Where will Latin America's Growth Come from? Discussion paper.

Molinas Vega, J. R., Paes de Barros, R., Saavedra, J., ... \& Hasan M. (2011). Do Our Children Have a Chance? World Bank, Washington DC. https://doi.org/10.1596/978-0-8213-8699-6

Mroz, T., \& Savage, T. H. (2006). The Long-term Effects of Youth Unemployment. The Journal of Human Resources, 41. https://doi.org/10.3368/jhr.XLI.2.259

Phillips, P. C. B., \& Hansen, B. E. (1990). Statistical Inference in Instrumental Variables Regressions with I(1) Processes. Review of Economic Studies, 57. https://doi.org/10.2307/2297545

Rodgers, J. R. (2004). Female-Headed Families: Why are They So Poor? Review of Social Economy, 22-47. https://doi.org/10.1080/758519572 
Ryan, P. (2001). The School-to-Work Transition: A Cross-National Perspective. Journal of Economic Literature, 39, 34-92. https://doi.org/10.1257/jel.39.1.34

Scarpetta, S., Sonnet, A., \& Manfredi, T. (2010). Rising Youth Unemployment During the Crisis: How to Preventt Negative Long Term Consequences on a Generation. OECD Social, Enployment and Migration Working Papers number 106, Paris.

Schwartz, J. Z., Andres, L. A., \& Dragoiu, G. (2009). Crisis in Latin America: Infrastructure Investment, Employment and the Expectations of Stimulus. Word Bank Working Paper 5009. https://doi.org/10.1177/097493060900100202

Swinton, A. (2010). Spillovers to Central America in Light of the Crisis: What a Difference a Year Makes. IMF Working Paper WP/10/35. https://doi.org/10.5089/9781451962765.001

TERCE. (2016). Tercer Estudio Regional Comparativo y Explicativo 2016. Unesco, Santiago de Chile.

Torres, J., \& McKenzie, A. (2020). Youth Unemployment in Uruguay. IMF working paper 20/281, Washington DC. https://doi.org/10.5089/9781513563947.001

World Bank. (2011). World Development Report 2011. Crime, Security and Development. Washington DC.

\section{Notes}

Note 1. The " $t$ " statistics are shown below the corresponding coefficients.

Note 2. These cointegration results can be obtained from the author.

Note 3. In equations (4) and (7) the qualitative variable Cuali3 takes the value of 1 in the period 2014-2016.

Note 4. The data on the number of homicides and incarcerated persons (averages 2008-2012), were taken from UNDP, Human Development Reports 2016.

Note 5. El Salvador did not participate. On an analysis of the quality of education in Latin American countries, see Cáceres (2018).

Note 6. These programs are described by Scarpetta, Sonnet and Manfredi (2010).

\section{Copyrights}

Copyright for this article is retained by the author(s), with first publication rights granted to the journal.

This is an open-access article distributed under the terms and conditions of the Creative Commons Attribution license (http://creativecommons.org/licenses/by/4.0/). 